\title{
Inhibin Beta B Chain
}

National Cancer Institute

\section{Source}

National Cancer Institute. Inhibin Beta B Chain. NCI Thesaurus. Code C28473.

Inhibin beta B chain (407 aa, $\sim 45 \mathrm{kDa}$ ) is encoded by the human INHBB gene. This protein is involved in the modulation of follitropin secretion. 